\title{
06 \\ MEMILIH PEMIMPIN DALAM PRAKTIK KEPEMIMPINAN ORGANISASI SEKOLAH DI ERA GLOBAL
}

Sunarta

\begin{abstract}
The leader and leadership courses have produced many hypotheses which haven't been solved from time to time. With regard to the demands of the globalization era recently, the successful organizations are those which are ruled by figures who have comparative and competitiveness strengths in many fields. In educational context, a leadership can be seen from the practice of school management starting from the basic educational level to the higher one. Educational leadership in the practice of school management expects that the one who plays roles and mandated as a leader must have specific requirements of a leader.

Social life in the globalization era has changed the mindsets and views of the people in the world at any level. This influences the awareness of striking for their personal and social rights in the organization. A leader is someone or subject that leads as leadership manifestation such as authority, responsibility, commands, and delegation to the subordinates in an organization. Meanwhile a leadership is an art of persuading, directing people through obedience, belief, respect, and cooperation based on enthusiasm to meet the goals, A Dale Timpe, (1987).

In order to give influence to the development of the organization, there are four leadership aspects that should be developed, such as (1) follower, (2) situation (3) communication and (4) leader.
\end{abstract}

Key words: leader, leadership, school organization, globalization era.

\section{A. Pendahuluan}

Sejak memasuki milenium ketiga hingga satu dekade terakhir ini yang sering disebut sebagai jaman global (global era), praktek kepemimpinan terus melahirkan tokoh-tokoh atau pemimpin baru yang mampu mengukir sejarah untuk masa yang akan datang. Pemimpin (leader) merupakan orang yang memiliki wewenang untuk membuat keputusan dalam suatu organisasi. Pemimpin juga bisa diartikan sebagai orang (sosok) yang memiliki kemampuan untuk mempengaruhi dan mengarahkan orang lain untuk melaksanakan tugasnya dalam mencapai tujuan pemimpin itu sendiri maupun tujuan organisasi yang dipimpinnya. Sedangkan kepemimpinan (leadership) dapat diartikan sebagai sifat dan watak dari sosok pemimpin dalam melaksanakan tugas, tanggung jawab, dan wewenangnya dalam suatu organisasi. Kepemimpinan dapat diartikan pula sebagai sifat-sifat dan bentuk-bentuk konkret dari jiwa seorang pemimpin, Hikmat, 2009:249. 
Dalam konteks pendidikan, kepemimpinan dapat dilihat dalam praktek penyelenggaraan manajemen sekolah mulai dari tingkat dasar sampai perguruan tinggi. Kepemimpinan pendidikan di dalam praktek manajemen sekolah mengharuskan seseorang yang berperan dan diberi amanah untuk menjadi pemimpin perlu memiliki berbagai persyaratan. Sebagai seorang penentu arah, penemu strategi, dan pembuat keputusan (decesion maker) dalam meraih keberhasilan organisasi, maka pemimpin harus memiliki persyaratan khusus dibanding orang-orang yang dipimpinnya. Demikian pula ketika pencapaian kinerja dan tujuan organisasi sekolah mengalami hambatan yang diakibatkan oleh hubungan kerja antar individu dengan individu, individu dengan kelompok, dan kelompok dengan kelompok, perkelahian antar pelajar, hamil pra nikah, narkoba, dan sejenisnya maka pemimpin harus bisa memerankan dirinya sebagai mediator dan problem solver atas masalah yang muncul.

Perubahan sosial yang cepat dan massif di berbagai bidang pada era global sebagai sebuah era baru yang terjadi sekarang ini telah menyadarkan kepada semua orang bahwa perubahan saat ini adalah realitas yang tidak bisa dielakkan. Kehidupan sosial pada era global telah merubah pola pikir (mindset) dan cara pandang masyarkat dunia di semua lapisan sehingga hal tersebut secara langsung maupun tidak langsung bisa mempengaruhi tingkat kesadaran dalam memperjuangkan hak-hak pribadi dan sosial. Dalam organisasi perusahaan seringkali muncul tuntutan penghapusan sistem kontrak (out sourcing), perbaikan sistem upah, kenaikan kesejahteraan, cuti, perpanjangan masa kerja dan sebagainyasehingga dapat memicu munculnya berbagai konflik internal maupun eksternal.

Tidak jauh beda dengan apa yang terjadi di organisasi perusahaan, dalam organisasi pendidikan juga muncul harapan besar agar terus meningkatkan profesionalisme demi perbaikan kualitas peserta didik/lulusan di satu sisi. Namun demikian tuntutan hak seperti tunjangan profesi, tunjangan jabatan, tunjangan khusus daerah tertinggal/terpencil di sisi yang lain. Pada kondisi yang demikian inilah sebuah organisasi pendidikan membutuhkan figur pemimpin yang mampu mengakomodir berbagai kepentingan, tuntutan, dan harapan seluruh anggota yang dipimpinnya.

\section{B. Pengertian Pemimpin}

Seperti telah disinggung dalam uraian di atas bahwa pemimpin (leader) adalah orang (subjek) yang memimpin sebagai bentuk manifestasi kepemimpinan seperti kekuasaan, tanggung jawab, perintah, dan pendelegasian kepada para bawahan atau pengikut dalam suatu organisasi. Pemimpin adalah penentu dalam pembuatan tujuan organisasi, baik tujuan jangka pendek, menengah, maupun jangka panjang. Dalam hal pemimpin sebagai penentu arah dan tujuan organisasi atas orangorang/bawahan yang dipimpinnya dalam kehidupan organisasi, 
mengandung maksud bahwa ada beberapa unsur penting dari makna pemimpin itu sendiri antara lain:

1. Unsur kekuasaan, yakni seorang pemimpin harus mampu mengendalikan dan menguasai semua struktur dan sistem yang dibangun di dalam kelompok atau organisasi.

2. Unsur perintah/instruksi, yakni bahwa seorang pemimpin memiliki wewenang penuh dalam memberi perintah, larangan, dan penugasan kepada para bawahannya.Instruksi yang diberikan harus tegas dan jelas

3. Unsur tanggung jawab, yakni bahwa pemimpin bertanggung jawab atas berbagai akibat/resiko atas apa yang ia diputuskan, ia perintahkan, dan ia jalankan bersama para pengikutnya menyangkut kinerja pribadi maupun organisasi.

4. Unsur pendelegasian, yakni sebagai pemimpin ia memiliki hak penuh dalam membagi tugas dan mendelegasikan sebagian kewewenangannya kepada orang yang dipilih dan dipercaya mampu mengemban tanggung jawab sebagi seorang pemimpin.

5. Unsur supervisi, yakni atas pemberian kewenangan dan pendelegasian tugas tersebut pemimpin berkewajiban memberikan pembinaan, pengarahan, serta pengembangan organisasi.

6. Unsur strategi, yakni pemimpin harus berperan sebagai seorang konseptor dalam menentukan strategi organisasi dalam menghadapi persaingan.

7. Unsur budaya, yakni pemimpin harus mampu menciptakan lingkungan kerja yang kondusif agar menjadi budaya kerja bagi seluruh anggota organisasi dalam mencapai tujuan bersama.

8. Unsur kharismatik, yakni pemimpin dalam menjalankan fungsifungsi kepemimpinannya harus ditunjang dengan kewibawaan soerang pemimpin. Hal ini sangat penting karena pemimpin yang tidak memiliki wibawa dan kharisma dihadapan bawahan akan kehilangan reputasi bahkan harga diri sebagai seorang pemimpin.

9. Unsur kejujuran, yakni jika pemimpin ingin berhasil harus meletakkan aspek kejujuran dalam dirinya dan orang-orang dibawahnya sehingga ada kesesuaian antara apa yang dikatakan, diimani, dan diperintahkan mencerminkan nilai-nilai kebaikan secara moral, agama, hukum, serta adat istiadat yang berlaku di lingkungan organisasi. Pemimpin harus berani menyuarakan hati nurani dan kebenaran.

Berdasarkan unsur-unsur di atas, pemimpin dalam kehidupan organisasi semestinya bisa memerankan dirinya sebagai seorang motivator, eksekutor, fasilitator, mediator, katalisator, kreator, stabilisator, dan dinamisator atas berbagai kepentingan orang-orang yang menjadi tanggung jawabnya. Pemimpin yang kreatif, akan tahu harus berbuat apa dan dengan cara bagaimana sesuatu itu dilakukan. Pemahaman terhadap ketepatan dalam memilih metode dan strategi atas berbagi persoalan yang muncul, mencirikan antara pemimpin kreatif-cerdas dengan pemimpin 
yang biasa-biasa saja. Pada saat apa seorang pemimpin menggunakan kekuatan motivasinya untuk meningkatkan semangat kerja bawahan, pada situasi yang bagaimana harus menggunakan peranannya sebagai seorang dinamisator, fasilitator, dinamisator bagi orang-orang yang dipimpinnya itulah pemimpin yang dibutuhkan pada setiap waktu, setiap tempat, dan setiap jaman.

\section{Karakterisitk Pemimpin}

Seorang pemimpin sebagai individu dan makhluk sosial memiliki pasti karakteristik khas yang dibawanya sejak lahir. Namun demikian ada pula seorang pemimpin yang memiliki karakter kuat sebagai ciri khas pribadi yang diperoleh dari hasil proses waktu panjang di berbagai peristiwa dan pengalaman yang dilaluinya. Sebagai seorang pemimpin karakteristik yang melekat pada dirinya akan menjadikan citra/image yang positif jika karakter yang dimilikinya positif, tetapi jika ternyata karakter yang dimilikinya lebih cenderung negatif, maka citra yang munculpun akan negatif. Untuk membangun citra positif dihadapan para pengikutnya, sorang pemimpin harus memiliki beberapa kemampuan/keahlian yang melekat pada dirinya antara lain:

a. Kompetensi teknis, penguasaan dalam suatu bidang tertentu (instruksional). Seorang pemimpin harus memiliki keunggulan dalam bidang tertentu dibanding yang lain sebagai merek pribadi yang relatif kekal. Pemimpin yang tidak memiliki kelebihan atas bidang teknis tertentu hanya akan menjadi pemimpin yang mudah dikendalikan bawahan dalam proses pengambilan keputusan-keputusan strategis.

b. Keahlian konseptual, yaitu suatu kemampuan berpikir abstrak atau strategis. Pemimpin harus bisa menunjukkan kepada orangorang yang menjadi pengikutnya bahwa dia layak menjadi pemimpin karena mampu menganalisa masalah organisasi, memiliki konsep dalam setiap penyelesaian masalah, dan mampu berpikir tentang masa depan mendahului orang-orang yang ada di lingkungannya.

c. Memiliki track record dalam menjalankan tugas dengan hasil terukur. Dengan bekal kemampuan teknis, keahlian konseptual, berwawasan luas, dan visioner maka seorang pemimpin akan memiliki pengalaman panjang seiring dengan perjalanan organisasi yang terus tumbuh dan maju.

d. Keahlian berkomunikasi, memotivasi, dan melimpahkan sebagian kewenangan yang dimiliki kepada bawahan yang tepat. Proses komunikasi yang dibangun oleh pemimpin yang pandai berkomunikasi akan menciptakan suasana hubungan kerja yang lebih kondusif dan komunikatif. Apabila proses komunikasi yang terbangun berjalan baik, maka setiap terjadi pendelegasian wewenang, pemberian perintah, dan larangan kepada bawahan akan dirasakan sebagai hal yang tidak menakutkan. 
e. Memiliki kemampuan mengenali, dan mengembangkan bakat anggotanya. Pemimpin dengan karakter ini selalu memberi ruang untuk maju berbagai bidang untuk menunjang keberhasilan kerja dan karir bagi bawahan. Pemimpin yang memiliki konsen seperti ini pada umumnya menjadi idola dan tempat pelarian bagi orang-orang yang ingin memperoleh pencerahan atas masalah kerja, kinerja, organisasi, karir, dan bahkan masalah yang bersifat pribadi sekalipun. Pemimpin dengan karakter ini adalah sosok pemimpin yang senang melahirkan pemimpin-pemimpin baru pada masanya, dan akan dikenang dengan indah pada waktu berikutnya.

f. Kemampuan mengambil keputusan yang sulit dengan cepat dan tepat sekalipun data yang tersedia tidak lengkap. Hanya pemimpin yang memiliki intuisi, insting, keberanian mengambil resiko, dan visioner yang bisa melakukan pengambilan keputusan secara cepat dan tepat walaupun dengan berbagai keterbatasan yang dimilikinya. Karakteristik pemimpin seperti ini tidak dimiliki oleh setiap orang yang menjadi pemimpin.

g. Kharismatik dalam arti berkarakter yang menunjukan kualitas kepribadian pemimpin. Pemimpin yang berkepribadian lembut, ramah, komunikatif, disiplin, jujur, dan bertanggung jawab akan memberikan dampak bagi bawahan dalam bekerja sehari-hari. Orang-orang yang menjadi bawahan dari seorang pemimpin dengan kepribadian mulia dan kharismatik memiliki kebanggaan yang sulit diukur dengan materi. Baginya pemimpin pujaannya adalah harga mati yang tidak bisa ditukar dengan apapun, bahkan nyawa sebagai tebusannya.

\section{Sifat Pemimpin}

Seorang pemimpin dalam praktek kepemimpinannya tidak bisa dipisahkan dengan sifat-sifat bawaan yang dimilikinya sebelum menjadi pemimpin. Sifat-sifat ini pada dasarnya akan mempengaruhi pembawaan sehari-hari seorang pemimpin dalam memimpin para bawahan. Pemimpin dengan sifat-sifat baik yang dimiliki dan melekat dalam perilaku kehidupan sosial sehari-hari, maka akan membawa pengaruh positif dan signifikan terhadap proses kepemimpinan yang dijalankan. Begitu pula sebaliknya, jika sang pemimpin telah membawa sifat-sifat buruk seperti suka marah, suka mencuri, berbohong, dan sering berbuat zalim kepada orang lain, maka hal tersebut akan berdampak negatif bagi kepemimpinan dimana ia menjadi pemimpin.

Beberapa sifat utama yang perlu dimiliki oleh seorang pemimpin agar membawa dampak kebaikan bagi dirinya sendiri maupun orang lain yang dipimpinnya antara lain adalah sebagai berikut:

a. Motivasi yang kuat untuk tujuan kemajuan bagi orang yang dipimpinnya. 
b. Membangun relasi baik internal maupun eksternal.

c. Idealisme yang tinggi untuk kemajuan organisasi.

d. Keterampilan mengelola berbagai sumber daya organisasi seperti orang, barang, uang, dan waktu.

e. Keterampilan berkomunikasi secara lisan dan tulisan dalam berbagai keadaan, baik di dalam maupun di luar organisasi.

f. Daya kreativitas dan inovasi yang membanggakan pribadi maupun kelompok sebagai kekuatan lain dalam mengembangkan kepemimpinannya.

g. Mampu berpikir kritis, logis, dan ilmiah.

h. Memiliki wawasan yang luas, pengalaman yang banyak, dan bertanggung jawab.

i. Mengedepankan nilai-nilai kejujuran dalam berbagai aspek kehidupan organisasi.

j. Sehat secara fisik maupun mental.

k. Bisa menjadi teladan bagi orang-orang yang dipimpinnya, baik perkataan/ucapan, perbuatan, dan tingkah lakunya.

\section{Pemimpin dan Manajer}

Pemimpin dengan keluasan wewenang dan tanggung jawab yang dimiliki dalam menentukan arah, tujuan, cita-cita, dan harapan yang dikemas dalam visi kepemimpinan yang diciptakan harus didukung oleh keterampilan mengelola berbagai sumber daya yang dimiliki organisasi. Dalam prkatek manajemen organisasi, pemimpin yang berhasil harus memiliki keahlian manajerial (managerial skill) yang baik. Pemimpin dan manajer sebagai satu kesatuan yang tidak bisa dipisahkan satu sama lain. Keberadaanya terpisah seperti dalam keping mata uang, pemimpin di satu sisi sedangkan manajer di sisi lain. Banyak manajer hebat tanpa harus menjadi pemimpin, tetapi untuk menjadi pemimpin hebat harus memiliki keahlian manaejerial yang bagus.

Dalam perspektif pendidikan, pemimpin yang berhasil adalah bagaimana membangun sekolah yang baik, melakukan perbaikan terus menerus, selalu belajar dan tumbuh tanpa mengesampingkan aturan sebagai pedoman, serta senantiasa bekerja dari pengalaman masa lalu demi peningkatan yang lebih baik di masa datang. Secara jelas perbedaan mendasar antara pemimpin dengan manajer dalam praktek menejemen sekolah dapat dilihat pada tabel. 


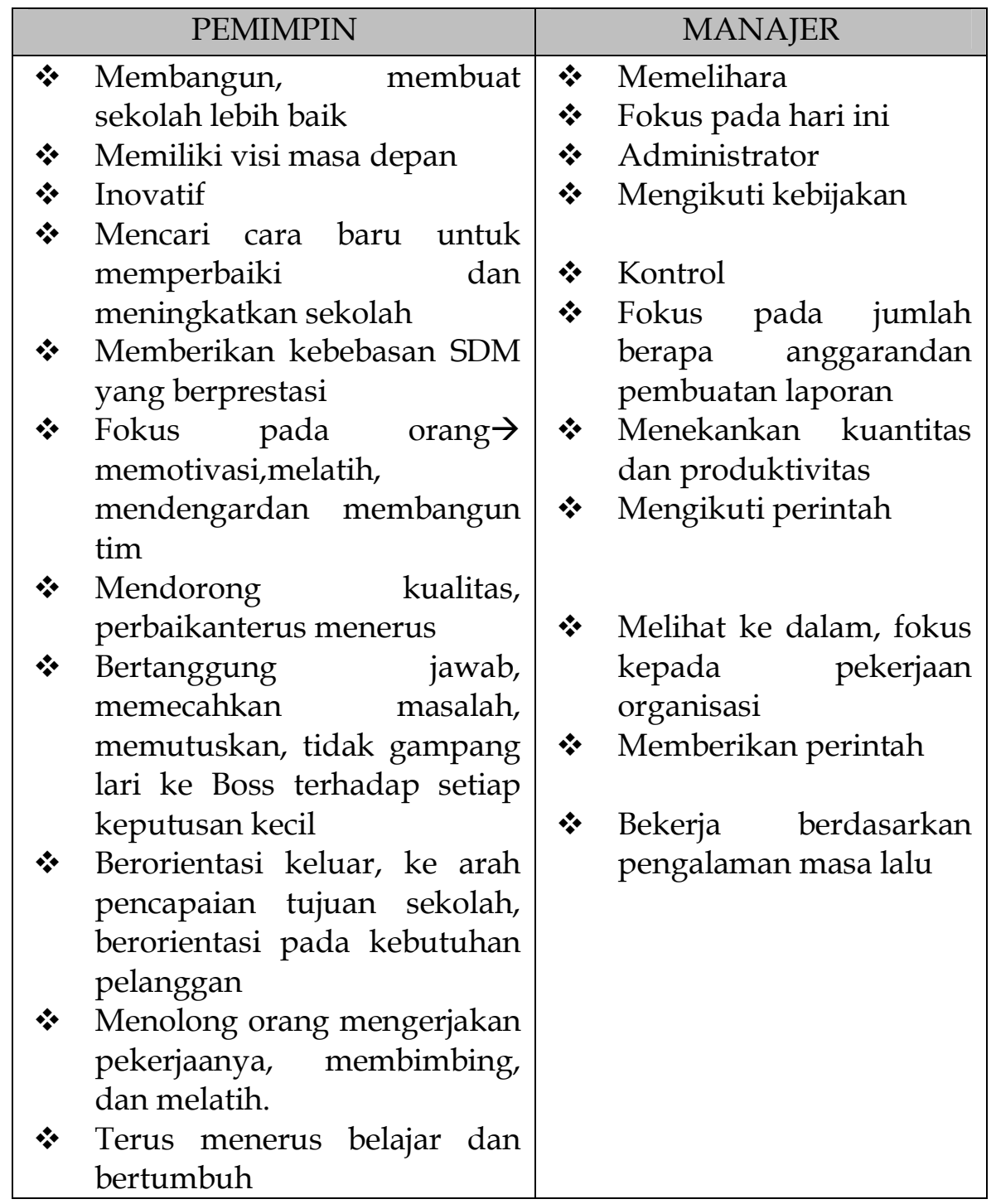

Source: 7 survival skills for a reengineered work, Yeomans,1996

\section{Pengertian Kepemimpinan}

Membicarakan masalah kepemimpinan merupakan bidang kajian yang sangat luas, karena tidak saja pada praktek organisasi dan sosial kemasyarakatan tetapi juga bidang pendidikan, pemasaran, industri, dan bisnis dalam berbagai level. Secara sederhana, apabila dalam suatu kelompok orang di suatu tempat kemudian satu orang diantaranya berinisiatif mengajak untuk melakukan kegiatan mengumpulkan sampah di jalanan agar lingkungan menjadi bersih, mengajak orang-orang di sekitarnya untuk belajar mengaji, mengajak bersikap hidup hemat, maka sebenarnya orang tersebut telah melakukan kegiatan kepemimpinan karena telah terpenuhinya unsur mengajak/menginisiasi, ada kegiatan, dan ada tujuan yang akan diwujudkan. 
Kepemimpinan oleh (Beerel, 2010: 64) dalam Leadership and Change Management mendefinisikan bahwa: "leadership is relational activity where an individuals guide or direct others (followers) to attain an objective or goal". Dengan kata lain dapat dinyatakan bahwa kepemimpinan merupakan aktivitas hubungan antar individu dalam memandu atau mengarahkan orang lain (pengikut) untuk mencapai suatu tujuan atau sasaran.Lebih lanjut pengertian tentang kepemimpinan juga disampaikan oleh (Yukl, 2006: 10) yang menyatakan bahwa: "leadership is process of influencing others to understand and agree about what need to be done and how to do it, and the process of facilitating individual and collective effort to accomplish shared objective". Kepemimpinan adalahproses mempengaruhiorang lain untukmengerti dan menyetujuitentang apa yangperlu dilakukandanbagaimana melakukannya, dan proses untuk memfasilitasiupayaindividu dankolektif untukmencapai tujuanbersama.

Kemudian oleh (Timpe, 1987), kepemimpinan didefinisikan sebagai suatu seni mempengaruhi dan mengarahkan orang dengan cara kepatuhan, kepercayaan, hormat, dan kerjasama yang bersemangat dalam mencapai tujuan bersama. Menurut (Hersy\&Blanchard, 1982), dikatakan bahwa "leadership is the process of influencing the activities of an individual or a group in effort toward goal achievement in a given situation". Sedangkan menurut (Anderson, 1998), juga dikatakan bahwa "leadership means using power to influence the throught and actions of others in such a way that achieve high performance".

Berdasarkan beberapa definisi diatas, maka dapat disimpulkan bahwa kepemimpinan sedikitnya memiliki tiga implikasi dasar. Pertama, kepemimpinan berarti kemampuan membangun semangat kerja, membujuk atau mempengaruhi, memotivasi, mengajak, dan mengarahkan orang lain kepada suatu tujuan yang telah ditentukan. Kedua, kepemimpinan merupakan suatu konsep relasi, artinya sebuah kepemimpinan hanya ada dan bisa berlangsung jika ada pengikut/bawahan. Kepemimpinan tanpa bawahan tidak memiliki makna apa-apa, sebaliknya bawahan tanpa adanya kepemimpinan akan liar dan sesat. Ketiga, kepemimpinan merupakan sebuah proses yaitu pemimpin memiliki kemampuan menghadapi tantangan bagi kemajuan organisasi, dengan indikator mampu memanfaatkan setiap peluang, dan berani mengambil resiko.

\section{Ciri Kepemimpinan}

Dari berbagai teori dan gaya kepemimpinan yang telah banyak diadopsi dan dipraktekkan ke dalam organisasi, sebenarnya tidak secara mutlak hasil dari teori-teori tertentu melainkan gabungan (mix) diantara sekian banyak teori yang ada. Teknik seseorang dalam memimpin organisasi sangat ditentukan oleh latar belakang individu dan situasi orang-orang yang dipimpinnya. 
Setiap pemimpin memiliki perbedaan dan keunikan masing-masing dalam memimpin. Kepemimpinan merupakan sebuah fenomena yang bersifat universal sehingga masing-masing pemimpin sangat sulit untuk di identifikasi gaya dan ciri-ciri khusus lainnya.

Melalui pendekatan berbagai teori kepemimpinan dan mengidentifikasi ciri-ciri secara umum, dapat diketahui bahwa pemimpin yang sukses salah satu ciri-cirinya adalah sebagai berikut:

a. Energik, cekatan, dan responsif terhadap tugas.

b. Terampil dalam bekerja dan komunikatif dengan semua orang.

c. Percaya diri dalam setiap menghadapi dan menyelesaikan masalah.

d. Komitmen terhadap waktu, tugas, dan kepada orang lain.

e. Toleran atas berbagai perbedaan yang dimiliki orang lain.

f. Adaptif terhadap perubahan lingkungan eksternal.

g. Ambisius dalam mewujudkan tujuan organisasi.

h. Tegas dalam setiap mengambil keputusan pada situasi apapun.

i. Bisa bekerjasama dengan para bawahan dan atasan.

j. Dapat diandalkan kapasitas dan kapabilitasnya dalam meningkatkan kinerja organisasi.

k. Dominan, menguasi masalah dan pandai mencari jalan keluarnya.

1. Penentu, mampu memerankan dirinya dalam pengambilan keputusan pad situasi sulit.

$\mathrm{m}$. Tanggung jawab, tidak mencari kambing hitam orang lain tetapi berani mengambil resiko walaupun sulit dilakukan.

n. Visioner, mampu melihat masa depan dan memutuskan segala sesuatu merujuk pada visi yang ada.

o. Jujur dan berani munyuarakan hati nurani.

p. Mampu menjadi teladan yang baik bagi anggotanya.

\section{Faktor-faktor Kepemimpinan}

Kepemimpinan sebagai suatu proses dalam mencapai suatu tujuan organisasi, sudah barang tentu melibatkan berbagai unsur subjek di dalamnya. Manakala unsur-unsur tersebut saling mempengaruhi satu sama lain tanpa dipandu oleh sistem yang diperankan oleh pemimpin, maka kepemimpinan yang dikembangkan akan mudah rapuh. Agar dalam proses kepemimpinan bisa membawa pengaruh kemajuan organisasi, perlu dikembangkan empat dimensi sebagai faktor kepemimpinan seperti pada tampilan gambar sebagai berikut. 


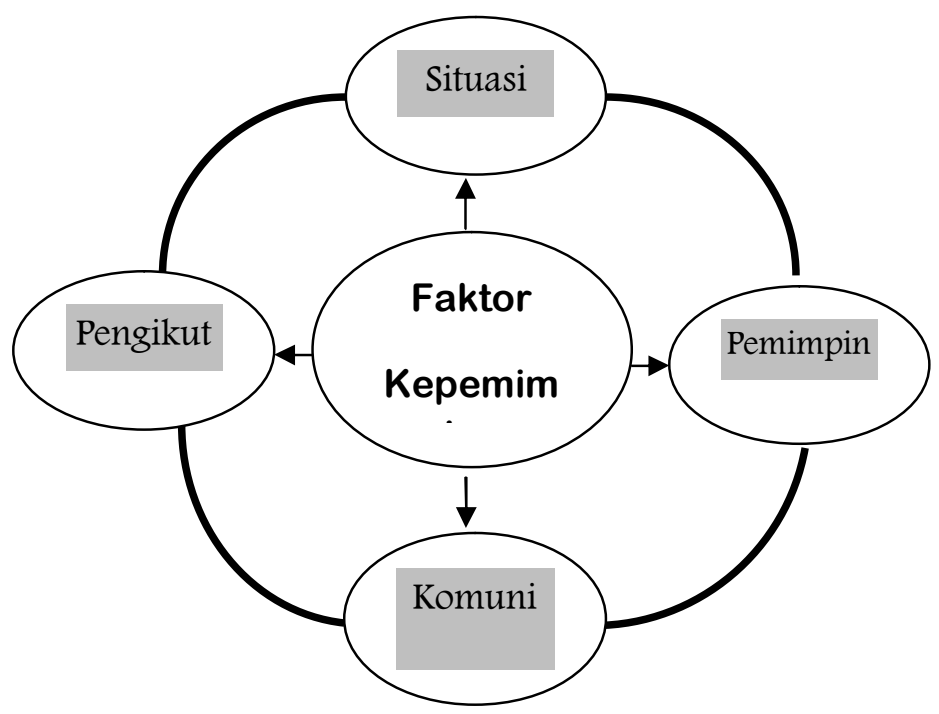

Dari tampilan gambar di atas dapat dijelaskan secara singkat bahwa, seorang pemimpin dalam berinteraksi dengan para bawahan selalu mengedepankan nilai-nilai kejujuran, kebaikan, dan moralitas sebagai orang yang dapat ditiru/dicontoh oleh orang lain. Kepemimpinan organisasi yang sukses bukan cerminan dari kesuksesan seorang pemimpin belaka, tetapi juga dipengaruhi faktor lain seperti bawahan yang rajin, lingkungan yang kondusif, dan saling pengertian antara pimpinan dan bawahan. Demikian pula pemimpin yang ingin berhasil harus memahami karakter dari orang-orang yang dipimpinnya. Pada dasarnya tiap bawahan memiliki sifat dan karakter yang berbeda-beda sehingga dalam menerapkan gaya kepemimpinan yang digunakan oleh pemimpin juga harus disesuaikan dengan kondisi masing-masing orang yang dipimpin.

Keharusan menerapkan gaya kepemimpinan tertentu pada masing-masing orang tertentu tidaklah sulit jika bawahan dan pemimpin memposisikan dirinya secara individual, akan tetapi hal ini sangat sulit apabila bawahan dalam arti kelompok. Seorang pemimpin akan selalu dihadapkan pada situasi yang berubah-ubah mengikuti perubahan situasi yang diciptakan melalui interaksi antar bawahan dengan bawahan. Kepemimpinan seseorang akan dikatakan berhasil ketika seseorang mampu menggunakan gaya tertentu pada situasi tertentu sesuai dengan karakter orang-orang yang menjadi bawahannya. Salah satu kunci suksesnya adalah kecepatan dan ketepatan menggunakan gaya tertentu untuk mengatasi permasalahan yang muncul dalam kondisi sulit. 
Ujian yang sebenarnya bagi seorang pemimpin adalah ketika menghadapi berbagai kepentingan dalam organisasi yang dipimpinnya. Jika pemimpin mampu mengindentifikasi berbagai persoalan, tuntutan, dan kendala-kendala teknis lainnya secara tepat dan merumuskannya menjadi sebuah solusi, maka sebenarnya $50 \%$ dari tugas pemimpin sudah selesai.

\section{Kepemimpinan Pendidikan}

Jika kita membicarakan kepemimpinan pendidikan, maka serta merta yang dimaksud adalah kepemimpinan kepala sekolah. Hal ini mungkin tidak salah, namun ada yang kurang pas karena membicarakan kepemimpinan pendidikan adalah mengenai proses, prosedur, sistem, budaya, kebiasaan, dan lingkungan keja di lembagalembaga pendidikan. Lembaga pendidikan juga tidak hanya sebatas pada pendidikan dasar dan menengah saja tetapi termasuk di dalamnya perguruan tinggi. Sedangkan membicarakan kepala sekolah berkaitan dengan sosok, figur, pemimpin, dan subjek dari pendidikan pada lembaga pendidikan itu sendiri. Sosok pemimpin dalam lembaga pendidikan dasar dan menengah seperti kepala sekolah dan guru, sedangkan sosok pemimpin pada perguruan tinggi adalah rektor, wakil rektor, dekan, wakil dekan, ketua jurusan, sekretaris jurusan dan sebagainya.

Sedangkan guru-guru pada pendidikan dasar dan menengah walaupun bukan merupakan pemimpin formal dalam struktural lembaga pendidikan, tetapi dalam proses belajar mengajar di kelas juga merupakan pemimpin bagi siswa. Menurut Katzenmeyer \& Moller, 2001, dalam (Sudarman Danim, 2010:177) dikatakan bahwa guru adalah pemimpin di dalam dan di luar kelas, dengan mengidentifikasi dan memberikan kontribusi kepada komuniktas pembelajar guru dan pemimpin dan mempengaruhi orang lain dalam peningkatan mutu praktik pendidikan. Begitu juga dengan dosendosen di perguruan tinggi, pada saat memberi materi perkuliahan di kelas/laboratorium sebenarnya merupakan pemimpin bagi para mahasiswanya dalam mencapai tujuan perkuliahan. Peranan pemimpin pendidikan dengan berbagai jenis dan ragamnya seperti di atas, akan sangat menentukan kualitas guru/dosen dalam menghasilkan lulusan.

\section{Kepemimpinan kepala sekolah}

Dalam konteks yang lebih sempit kepemimpinan pendidikan dapat dimaknai sebagai kepemimpinan kepala sekolah. Kepala sekolah dalam menjalankan fungsi organisasi harus didukung dengan penguasaan leadership skill dan managerial skill yang mumpuni sesuai tuntutan jamannya. Selain itu dalam mengelola berbagai sumber daya yang dimiliki oleh sekolah, kepala sekolah harus mampu memerankan dirinya sebagai penunjuk arah bagi para guru dan orang-orang yang menjadi pengikutnya. Pada 
banyak kejadian di dalam praktek kepemimpinan kepala sekolah, berbagai masalah muncul dalam berbagai situasi yang tidak diperhitungkan sebelumnya.

Kompleksitas masalah yang dihadapi kepala sekolah mengharuskan dirinya memerankan peran, menciptakan visi yang menantang untuk di wujudkan bersama elemen organisasi yang lain. Kepala sekolah juga harus memotivasi, menggerakkan, menginspirasi, dan mendorong para pengikutnya ke arah tujuan yang ditetapkan sebelumnya. Pendekatan kepemimpinan kepala sekolah yang sering digunakan dalam manajemen sekolah adalah pendekatan rasional dan moral. Pendekatan rasional mendasarkan pada pemenuhan hak dan kewajiban melalui perangkat aturan dan tata tertib yang disepakati bersama. Kemudian pendekatan moral lebih pada bagaimana mengasah kepekaan dan empaty setiap individu dalam memandang dirinya, orang lain, dan lingkungannya. Melalui dasar-dasar moralitas kepemimpinan kepala sekolah bisa menekan sifat dan tindakan mementingkan pribadi para guru untuk kepentingan yang lebih luas.

Tidak bisa dipungkiri bahwa pada interaksi sehari-hari kepala sekolah seringkali menggunakan gaya kepemimpinan transaksional untuk lebih menarik dan meyakinkan para guru dalam mencapai tujuan. Kepemimpinan transaksional sebenarnya lebih cocok digunakan untuk lembaga politik atau partai, tetapi dalam prakteknya untuk tujuan tertentu seperti himbauan moral, kejujuran, keadilan, komitmen, loyalitas, dan tanggung jawab terhadap tugas profesi masih sering digunakan di sekolah. Pada situasi tertentu kepemimpinan transaksional lebih baik daripada transformasional, begitu pula sebaliknya pada waktu tertentu kepemimpinan transformasional lebih baik. Keberhasilan kepemimpinan di sekolah sangat dipengaruhi oleh hal-hal pokok meliputi: kepribadian, keteladanan, pemahaman konsep, kompetensi manajerial, dan profesionalisme kepala sekolah. Kepala sekolah yang berhasil adalah kepala sekolah yang dapat memanfaatkan kritik, saran dan masukan dari siapapun sebagai bahan pijakan untuk maju dan memperbaiki kekurangannya. http://gurupinilih.blogspot.com, diunduh tanggal 9 Nopember 2011

\section{Fungsi-fungsi kepemimpinan kepala sekolah}

Menurut Sri Bagus Darmoyo, 2008, dinyatakan bahwa sedikitnya terdapat tujuh fungsi pokok kepemimpinan modern bagi kepala sekolah antara lain:

a. Kepala Sekolah sebagai educator, kepala sekolah diharapkan mampu membina kepribadian dan perilaku guru dan memotivasi guru dan siswa untuk berprestasi. Kepala sekolah adalah guru yang mendapat tugas tambahan sebagai kepala sekolah dan kepala sekolah sebagai guru (edukator) tidak dapat lepas dari tugas utamanya yaitu mendidik. Dalam hal ini sebagai 
kepala sekolah, yang dididik bukan hanya siswa, akan tetapi seluruh staf dan seluruh warga sekolah.

b. Kepala sekolah sebagai manager: sebagai seorang manajer, kepala sekolah dalam melaksanakan tugasnya harus dengan prinsipprinsip manajemen yang benar. Melalui fungsi-fungsi manajemen seperti perencanaan, pengorganisasian, penggerakan dan pengedalian, maka kepala sekolah harus mampu mengimplementasikan seluruh aspek kegiatan yang ada di sekolah sesuai prinsip dan fungsi manajemen pada umumnya.

c. Kepala sekolah sebagai administrator: sebagai administrator, berarti kepala sekolah harus menjalankan seluruh kegiatan administrasi sekolah, dan bertanggung jawab atas terlaksananya seluruh kegiatan administrasi seperti rekrutmen, seleksi SDM, penganggaran, sarana prasarana, kurikulum, serta hal-hal lain yang melekat pada kepala sekolah.

d. Kepala sekolah sebagai supervisor: sebagai supervisor, kepala sekolah harus melakukan supervisi pada seluruh kegiatan yang ada di sekolah, dan melakukan kontrol agar seluruh kegiatan berjalan sesuai dengan rencana yang telah ditetapkan sebelumnya.

e. Kepala sekolah sebagai leader: bahwa sebagai seorang leader atau pemimpin, kepala sekolah harus menjalankan fungsi kepemimpinan terhadap orang-orang yang menjadi tanggung jawabnya. Kepala sekolah mampu menunjukkan kepribadian yang patut diteladani oleh guru dan stafnya. Sebagai sosok pemimpin, kepala sekolah harus menetapkan garis-garis besar kebijakan, program, dan kegiatan-kegiatan operasional, sehingga ketercapaian atau kesuksesan atas pelaksanaan seluruh aspek kebijakan sekolah menjadi penting.

f. Kepala sekolah sebagai innovator: sebagai inovator, kepala sekolah secara terus menerus harus mencari dan menciptakan jalan baru yang belum pernah ditemukan orang lain agar sekolah bisa berkembang mengikuti perkembangan jaman lebih dulu daripada sekolah lain. Selain itu kepala sekolah diharapkan mampu bekerja secara konstruktif, kreatif, delegatif dan integratif.

g. Kepala sekolah sebagai motivator: kepala sekolah harus senantiasa memberikan motivasi dan dorongan kepada semua orang yang menjadi pengikutnya untuk maju, berkembang sesuai dengan keinginan individu, guna memajukan organisasi yang dipimpinnya untuk jangka pendek maupun jangka panjang. 


\section{E. Penutup}

Pemimpin yang cocok pada lembaga pendidikan saat ini dan mendatang adalah sosok yang memiliki sifat kreatif, inovatif, suportif, inspiratif, intuitif, adaptif, partisipatif, dan pribadi yang memiliki karakter jujur, tanggung jawab, mampu berpikir konsep, logis, ilmiah, visioner, bisa menjadi contoh, memiliki leadership skill sekaligus managerial skill yang baik, sehat jasmani-rohani. Dengan sifat dan karakter seperti di atas, pada umumnya gaya kepemimpinan yang cocok untuk diterapkan dalam organisasi sekolah adalah gaya kepemimpinan demokratis, kharismatik, transformasional, dan transaksional. Kombinasi dari empat gaya kepemimpinan tersebut akan berjalan baik dan ideal jika didukung oleh faktor komunikasi, pengikut, situasi, dan faktor pemimpin itu sendiri.

\section{Daftar Pustaka}

Beerel, Annabel. (2010). Leadership and Change Management, Los Angeles, SAGE.

Burt Nanus. (2001). Kepemimpinan Visioner, Prenhalindo, Jakarta.

Gary Dessler. (1997). Human Resource Management, Prentice Hall, USA.

Hikmat.(2009). Manajemen Pendidikan, Pustaka Setia, Bandung.

Hoy, Wayne K. \& Miskel, Cecil G. (2008). Educational Administration,

Theory, Research, and Practice, $8^{\text {th }}$ edition, Mcgraw Hill.

Ken Blancard. (2002). Empowerment(Take More Than a Minute), Amara

Books, Yogyakarta.

Sudarman Danim.(2010). Kepemimpinan Pendidikan, Alfa Beta, Bandung.

Tilaar, HAR. (1997). Pengembangan Sumber Daya manusia dalam Era

Globalisasi, Visi, Misi dan Program Aksi Pendidikan dan

Pelatihan Menuju 2020. Jakarta: Grasindo.

Triantoro Safaria. (2004). Kepemimpinan, Graha Ilmu, Yogyakarta.

Yukl, Gary. (2006). Leadership in organization, $6^{\text {th }}$ editon, Prentice-Hall. http://gurupinilih.blogspot.com/model-kepemimpinan-pendidikan.html. 